\title{
Effect of Heat Units on Growth and Yield of Groundnut Varieties under Different Planting Methods in Summer Season
}

\author{
S. S. Khade ${ }^{1}$, B. V. Asewar ${ }^{2}$, B. R. Bobade ${ }^{3 *}$ and Lalita Verma ${ }^{2}$ \\ ${ }^{1}$ Agricultural Meteorology, ${ }^{2}$ Department of Agronomy, ${ }^{3}$ FASAL, Agricultural Meteorology, \\ VNMKV, Parbhani (M.S), India \\ *Corresponding author
}

\section{A B S T R A C T}

\begin{tabular}{l} 
Ke y w o r d s \\
GDD, HTU, \\
Groundnut, \\
Varieties and Land \\
configurations \\
\hline Article Info \\
\hline $\begin{array}{l}\text { Accepted: } \\
\text { 12 January } 2021 \\
\text { Available Online: } \\
\text { 10 February } 2021\end{array}$ \\
\hline
\end{tabular}

\section{Introduction}

Among oilseed crops, groundnut occupies prime position in terms of acreage and production in India. Its high oil and protein content, ability to withstand water deficit conditions and remunerative price in market make it an attractive crop to farmers. Due to these agronomic and economic advantages it is an indispensable crop in the cropping pattern of Marathwada region of Maharashtra. India occupies first place in regard to acreage (6.40 M.ha.) and second in production (6.25 M.tones). In India during 2014 it was grown in an area of 55.27 lakh ha with total production of 96.72 lakh tones and productivity $1804 \mathrm{~kg} / \mathrm{ha}$. About $80 \%$ of area under groundnut is concentrated in 5 states as Gujrat rank first in area and production of groundnut, it contributes $38 \%$ of total production of India followed by Andhra Pradesh 16\%, Tamil Nadu 14\% Rajasthan 9\%, Maharashtra 8.22\% and Karnataka 8\%. In Maharashtra during 2014 area under groundnut was 2.67 lakh /ha, Production was 3.25 lakh tones and productivity was 1217 $\mathrm{kg} / \mathrm{ha}$. (www.indiastat.com).

In Marathwada weather conditions are prevailed during post monsoon season match 
with the growth phases of groundnut i.e. warm weather $\left(18-37{ }^{0} \mathrm{C}\right)$ expansive phenophase favours adequate vegetative growth and long cool period which restricts vegetative growth followed by warm period favours pod development.

Broad bed furrow provide favourable soil atmosphere by lowering the bulk density in the surface layer with low soil strength leading good root development, better nodulation.

Temperature is an important environmental factor influencing the growth and development of crop plants. Influence of temperature on phenology and yield of crop plants can be studied under field condition through accumulated heat units system (Bishnoi et al., 1995). Temperature based agrometeorological indices such as Growing degree day (GDD), Heliothermal unit (HTU) and Thermal use efficiency (TUE) are very useful for predicting the growth and yield of crops.

The growing degree day (GDD) is a simple tool to find out the relationship between plant growth, maturity and mean air temperature. A degree day or a heat unit is the departure from the mean daily temperature above the minimum threshold temperature (Basu et al., 2012). GDD requirement indicates the thermal status for the onset of a particular phenophase in the crop.

\section{Importance of Heat Units (HU) in Crop Production}

The amount of heat energy an organism accumulates over a period of time is often expressed as a "growing degree-day" (GDD). The growth rate of many organisms is controlled by temperature. Growers use a concept related to degree-days called growing degree-days (GDDs), sometimes called heat

\section{Applications of HU in Crop Production}

(i) Assess the suitability of a region for production of a particular crop.(ii) Determine the growth-stages of crops. (iii) Predict best timing of fertilizer or herbicide and plant growth regulator application. (iv) Estimate the heat stress on crops. (v) Predict the maturity (physiological) and harvest dates. (vi) Tool for managing growth regulators or harvest aids; (vii) Ideal unit in crop weather model.

\section{Calculation of GDD}

"Growing degree days" (abbreviated GDD or DD) is a way of assigning a heat value to each day. Growing degree days are calculated in each day using the maximum daily temperature (Tmax), the minimum daily temperature (Tmin), and a base temperature (Tbase).

$\mathrm{GDD}=\frac{\mathrm{Tmax}+\mathrm{Tmin}}{2}-\mathrm{Tbase}$

$\mathrm{T}$ base - The base temperature or threshold temperature- is the temperature below which no growth takes place. This varies with different crops. Generally, the threshold temperatures are higher values for tropical crops and lower values for temperate crops.

\section{Helio-thermal units (HTU)}

The product of GDD and corresponding actual sunshine hours for that day were computed on daily basis as:

\section{$\mathrm{HTU}=\mathrm{GDD} \times$ Actual Sunshine hours}

In present study, an attempt is made to predict growth and yield of groundnut based on GDD and HTU. Heat use efficiency of three varieties of groundnut under different planting methods in summer season. 


\section{Materials and Methods}

A field experiment was conducted at research farm, Department of Agronomy, Vasantrao Naik Marathwada Agricultural University, Parbhani, in summer season of 2014. The soil was medium black clayey in texture having bulk density $1.33 \mathrm{~g} \mathrm{~cm}^{-3}$, Particle density 2.66 $\mathrm{g} \mathrm{cm}^{-3}$, Soil pH 8.07, EC $0.37 \mathrm{dsm}^{-1}$ at $25^{\circ} \mathrm{c}$, Organic carbon $0.34 \mathrm{~g} \mathrm{~kg}^{-1}$, Available Nitrogen $190.61 \mathrm{~kg} \mathrm{ha}^{-1}$, Available Phosphorous $11.52 \mathrm{~kg} \mathrm{ha}^{-1}$, Available Potash $285.15 \mathrm{~kg} \mathrm{ha}^{-1}$.

The experiment was laid out in split plot design with three replications and 12 treatments. The main plot compromised three land configurations $\mathrm{L}_{1}$ Ridges and furrow, $\mathrm{L}_{2}$ Broad bed furrow, $\mathrm{L}_{3}$ Sara and $\mathrm{L}_{4}$ flat bed. Sub plot treatments varieties as $\mathrm{V}_{1}$-TAG 24, $\mathrm{V}_{2}$ - SB-XI and $\mathrm{V}_{3}$-LGN-1.The gross plot size was $5.4 \mathrm{~m} \times 4.2 \mathrm{~m}$ and net plot size was $4.8 \mathrm{~m}$ $\times 3.8 \mathrm{~m}$.

The sowing was done by dibbling method on $27^{\text {th }}$ February 2014 at the spacing of $30 \times 10$ $\mathrm{cm}$. The recommended cultural practices and plant protection measure were undertaken. The recommended dose of fertilizer (25:50:00 $\mathrm{kg}$ NPK $\mathrm{ha}^{-1}$ ) was applied at the time of sowing through urea and DAP. The rainfall received during crop growing season was $177.2 \mathrm{~mm}$ in 2014 summer season.

\section{Results and Discussion}

Growing degree days and Heliothermal Units required for different phenophases of three groundnut varieties are presented in table 1. In general long duration variety required more GDD as compared to short duration variety. The GDD requirement for different phenophases varied depending upon the duration of a particular phenophase. Maximum GDD requirement was observed in $\mathrm{P}_{7}$ and $\mathrm{P}_{8}$ (pod initiation to harvest) and the minimum was recorded in $\mathrm{P}_{1}$ to $\mathrm{P}_{2}$ (sowing to complete emergence) (Fig. 1-3 and Table 15).

Among the three varieties, as $\mathrm{V}_{1}$ short duration GDD requirement was minimum in TAG-24 and SB-XI long duration GDD requirement was maximum in SB-XI and optimum in LGN-1. The variation in GDD requirement depends on the duration of a particular phenophase (Borreani et al., 2007).

Table.1 Phenophases-wise requirement of GDD and HTU of different groundnut varieties

\begin{tabular}{|c|c|c|c|c|c|c|}
\hline \multirow{2}{*}{$\begin{array}{l}\text { Phenological } \\
\text { stages }\end{array}$} & \multicolumn{2}{|c|}{ TAG-24(V $\left.V_{1}\right)$} & \multicolumn{2}{|c|}{ SB-XI $\left(V_{2}\right)$} & \multicolumn{2}{|c|}{ LGN-1 $\left(\mathbf{V}_{\mathbf{3}}\right)$} \\
\hline & GDD & HTU & GDD & HTU & GDD & HTU \\
\hline $\mathbf{P}_{1}$ & 52 & 468 & 77 & 671 & 64 & 585 \\
\hline $\mathbf{P}_{2}$ & 99 & 804 & 125 & 981 & 112 & 882 \\
\hline $\mathbf{P}_{\mathbf{3}}$ & 383 & 3251 & 571 & 4992 & 498 & 4289 \\
\hline $\mathbf{P}_{4}$ & 843 & 7555 & 1005 & 8820 & 913 & 8176 \\
\hline $\mathbf{P}_{5}$ & 1162 & 10418 & 1385 & 12463 & 1254 & 11375 \\
\hline$P_{6}$ & 1531 & 13650 & 1735 & 15602 & 1608 & 14419 \\
\hline $\mathbf{P}_{7}$ & 1809 & 16268 & 2042 & 18011 & 1941 & 17206 \\
\hline $\mathbf{P}_{8}$ & 2154 & 19013 & 2366 & 20666 & 2251 & 19855 \\
\hline
\end{tabular}

$\mathrm{P}_{1}$ : sowing to germination, $\mathrm{P}_{2}$ : Complete emergence,

$\mathrm{P}_{4}$ : Vegetative stage $\quad \mathrm{P}_{5}$ : Flowering stage

$\mathrm{P}_{7}$ : Pod initiation to pod formation

$\mathrm{P}_{3}$ : Seedling stage

$\mathrm{P}_{6}$ : Pegging

$\mathrm{P}_{8}$ : Physiological maturity 
Table.2 Effect of different treatments on biological yield, pod yield and haulm yield of groundnut

\begin{tabular}{|l|c|c|c|}
\hline Treatments & $\begin{array}{l}\text { Biological yield } \\
\text { Kg/ha }\end{array}$ & $\begin{array}{l}\text { Pod yield } \\
\text { Kg/ha }\end{array}$ & $\begin{array}{l}\text { Haulm yield } \\
\text { Kg/ha }\end{array}$ \\
\hline Land configuration & \multicolumn{3}{|c|}{} \\
\hline $\mathbf{L}_{\mathbf{1}}$ Ridges \& Furrow & 4062 & 1638 & 2320 \\
\hline $\mathbf{L}_{\mathbf{2}}$ Broad Bed Furrow & 4542 & 1872 & 2670 \\
\hline $\mathbf{L}_{\mathbf{3}}$ Sara & 3978 & 1562 & 2275 \\
\hline $\mathbf{L}_{\mathbf{4}}$ Flat bed & 3790 & 1480 & 2203 \\
\hline Varieties & & & \\
\hline $\mathbf{V}_{\mathbf{1}}$ TAG-24 & 4631 & 1974 & 2657 \\
\hline $\mathbf{V}_{\mathbf{2}}$ SB-XI & 3965 & 1582 & 2328 \\
\hline $\mathbf{V}_{\mathbf{3}}$ LGN-1 & 4295 & 1778 & 2400 \\
\hline
\end{tabular}

Table.3 Phenophases wise weather parameters data of Variety TAG-24

\begin{tabular}{|c|c|c|c|c|c|c|c|c|c|}
\hline $\begin{array}{c}\text { Phenological } \\
\text { Stages }\end{array}$ & \multicolumn{9}{|c|}{ Weather parameters } \\
\cline { 2 - 11 } & Rainfall & $\begin{array}{c}\text { Rainy } \\
\text { days }\end{array}$ & $\begin{array}{c}\text { T } \\
\text { max }\end{array}$ & T min & $\begin{array}{c}\text { T } \\
\text { mean }\end{array}$ & BSS & WV & GDD & HTU \\
\hline $\mathbf{P}_{\mathbf{1}}$ & 19.8 & 3 & 30.9 & 15.3 & 23.1 & 9 & 4.7 & 52.4 & 467.58 \\
\hline $\mathbf{P}_{\mathbf{2}}$ & 7.2 & 2 & 28.4 & 15.1 & 21.7 & 7.1 & 8 & 99.4 & 803.82 \\
\hline $\mathbf{P}_{\mathbf{3}}$ & 66.5 & 4 & 35.5 & 18 & 25.8 & 8.5 & 4.6 & 383.4 & 3250.6 \\
\hline $\mathbf{P}_{\mathbf{4}}$ & 0.5 & 0 & 38.6 & 19.7 & 29.1 & 9.4 & 3.6 & 843.3 & 7555.09 \\
\hline $\mathbf{P}_{\mathbf{5}}$ & 6.7 & 2 & 39.8 & 22.6 & 31.2 & 9 & 4.7 & 1161.7 & 10417.65 \\
\hline $\mathbf{P}_{\mathbf{6}}$ & 10.8 & 2 & 38.3 & 22.7 & 30.5 & 8.7 & 5.4 & 1531.4 & 13649.97 \\
\hline $\mathbf{P}_{\mathbf{7}}$ & 14.5 & 2 & 42.2 & 24 & 33.1 & 9.5 & 5.7 & 1808.9 & 16268.35 \\
\hline $\mathbf{P}_{\mathbf{8}}$ & 27 & 5 & 40.3 & 25.8 & 33 & 7.9 & 7.1 & 2154.4 & 19013.4 \\
\hline
\end{tabular}

Table.4 Phenophases-wise weather parameters of Groundnut Variety LGN-1

\begin{tabular}{|c|c|c|c|c|c|c|c|c|c|}
\hline \multirow{2}{*}{$\begin{array}{c}\text { Pheno } \\
\text { phases }\end{array}$} & \multicolumn{70}{|c|}{ Weather Parameters } \\
\cline { 2 - 11 } & Rainfall & $\begin{array}{c}\text { Rainy } \\
\text { day }\end{array}$ & Tmax & Tmin & Tmean & BSS & WV & GDD & HTU \\
\hline $\mathbf{P}_{\mathbf{1}}$ & 19.8 & 3 & 30.6 & 15 & 22.8 & 9.1 & 5.1 & 64.3 & 584.99 \\
\hline $\mathbf{P}_{\mathbf{2}}$ & 7.2 & 3 & 27.7 & 16 & 21.8 & 6.2 & 8.6 & 111.7 & 882.1 \\
\hline $\mathbf{P}_{\mathbf{3}}$ & 66.5 & 3 & 35 & 18.5 & 26.8 & 8.7 & 4.1 & 497.7 & 4289.27 \\
\hline $\mathbf{P}_{\mathbf{4}}$ & 4.2 & 1 & 38.7 & 20 & 29.3 & 9.3 & 4 & 913.3 & 8176.42 \\
\hline $\mathbf{P}_{\mathbf{5}}$ & 8.6 & 2 & 40 & 22.5 & 31.3 & 9.4 & 4.5 & 1254.2 & 11375.23 \\
\hline $\mathbf{P}_{\mathbf{6}}$ & 15.2 & 2 & 38.8 & 22.8 & 30.8 & 8.5 & 5.7 & 1608.1 & 14418.7 \\
\hline $\mathbf{P}_{\mathbf{7}}$ & 18.5 & 4 & 42.2 & 25.3 & 33.8 & 8.4 & 6.2 & 1940.9 & 17206.27 \\
\hline $\mathbf{P}_{\mathbf{8}}$ & 37.5 & 4 & 38.1 & 26.3 & 32.2 & 8.2 & 7.6 & 2251.4 & 19855.02 \\
\hline Total & 177.5 & 22 & & & & & & & \\
\hline Mean & & & 36.38 & 20.8 & 28.6 & 8.4 & 5.7 & & \\
\hline
\end{tabular}


Table.5 Phenophases wise weather parameters data of groundnut Variety SB-XI

\begin{tabular}{|c|c|c|c|c|c|c|c|c|c|}
\hline $\begin{array}{c}\text { Pheno } \\
\text { phases }\end{array}$ & \multicolumn{9}{|c|}{ Weather Parameters } \\
\hline & Rainfall & $\begin{array}{c}\text { Rainy } \\
\text { day }\end{array}$ & Tmax & Tmin & Tmean & BSS & WV & GDD & HTU \\
\hline $\mathbf{P}_{\mathbf{1}}$ & 22.8 & 4 & 30.5 & 15.3 & 22.9 & 8.7 & 5.8 & 77.3 & 670.8 \\
\hline $\mathbf{P}_{\mathbf{2}}$ & 10.2 & 3 & 27.4 & 16.4 & 21.9 & 6.4 & 8 & 125.1 & 981.3 \\
\hline $\mathbf{P}_{\mathbf{3}}$ & 60.5 & 2 & 35.7 & 18.5 & 27.1 & 8.9 & 3.9 & 570.8 & 4992.2 \\
\hline $\mathbf{P}_{\mathbf{4}}$ & 5.2 & 1 & 38.6 & 20.9 & 29.7 & 9.2 & 4.2 & 1005 & 8820.2 \\
\hline $\mathbf{P}_{\mathbf{5}}$ & 9.6 & 2 & 39.9 & 22.3 & 31.1 & 9.7 & 4.9 & 1384.8 & 12462.8 \\
\hline $\mathbf{P}_{\mathbf{6}}$ & 14.2 & 2 & 40.1 & 23.7 & 31.9 & 8.8 & 5.6 & 1735.4 & 15601.6 \\
\hline $\mathbf{P}_{\mathbf{7}}$ & 18.5 & 4 & 41.2 & 25.9 & 33.6 & 7.7 & 6.6 & 2042.2 & 18010.9 \\
\hline $\mathbf{P}_{\mathbf{8}}$ & 38 & 3 & 37.2 & 25.7 & 31.7 & 8.1 & 9.1 & 2365.6 & 20665.9 \\
\hline Total & 179 & 21 & & & & & & & \\
\hline Mean & & & 36.33 & 21.1 & 28.9 & 8.4 & 6.1 & & \\
\hline
\end{tabular}

Phenophases wise Graphs of groundnut varieties

Fig.1 Variety TAG-24
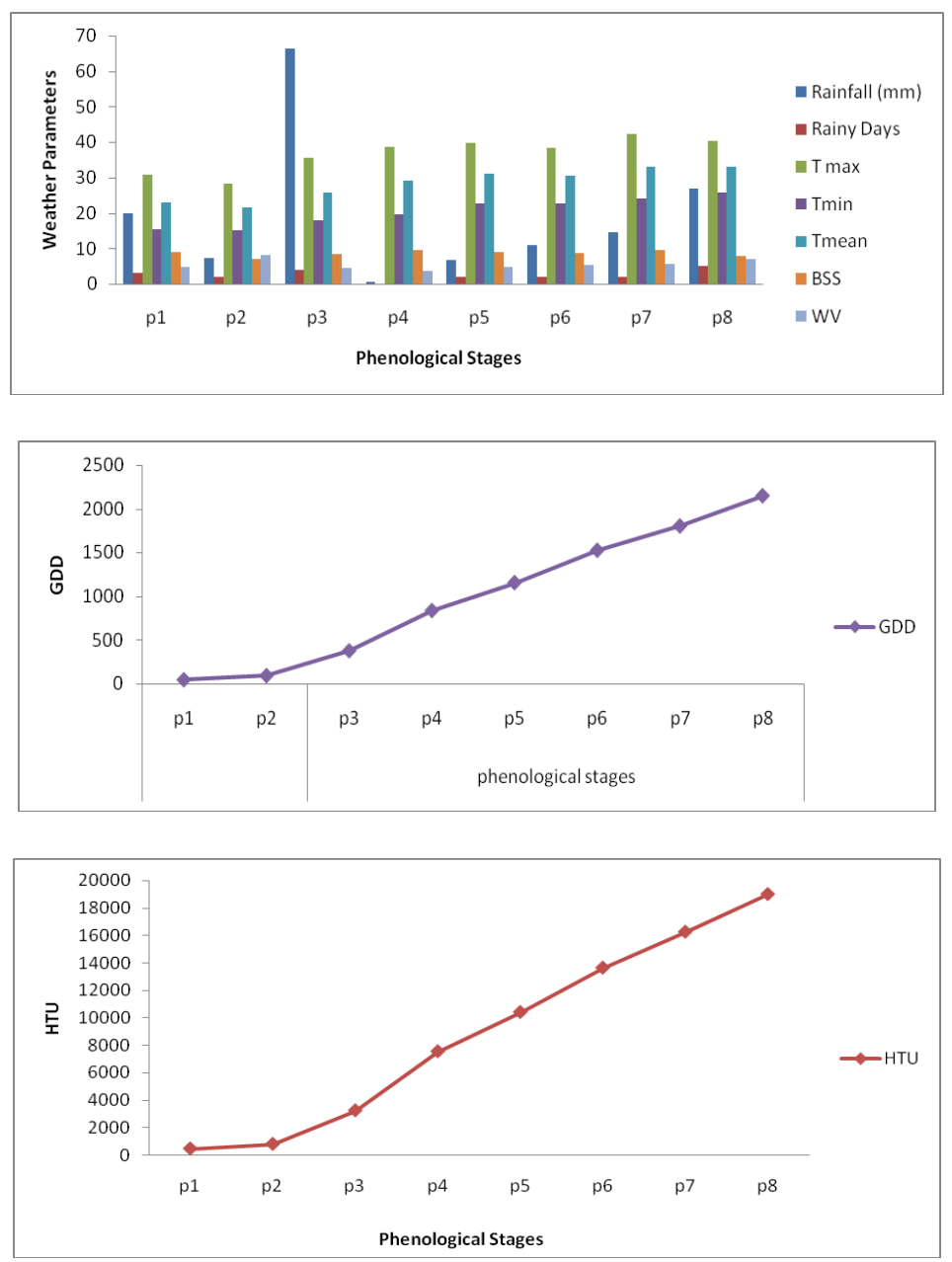
Fig.2 Variety LGN-1
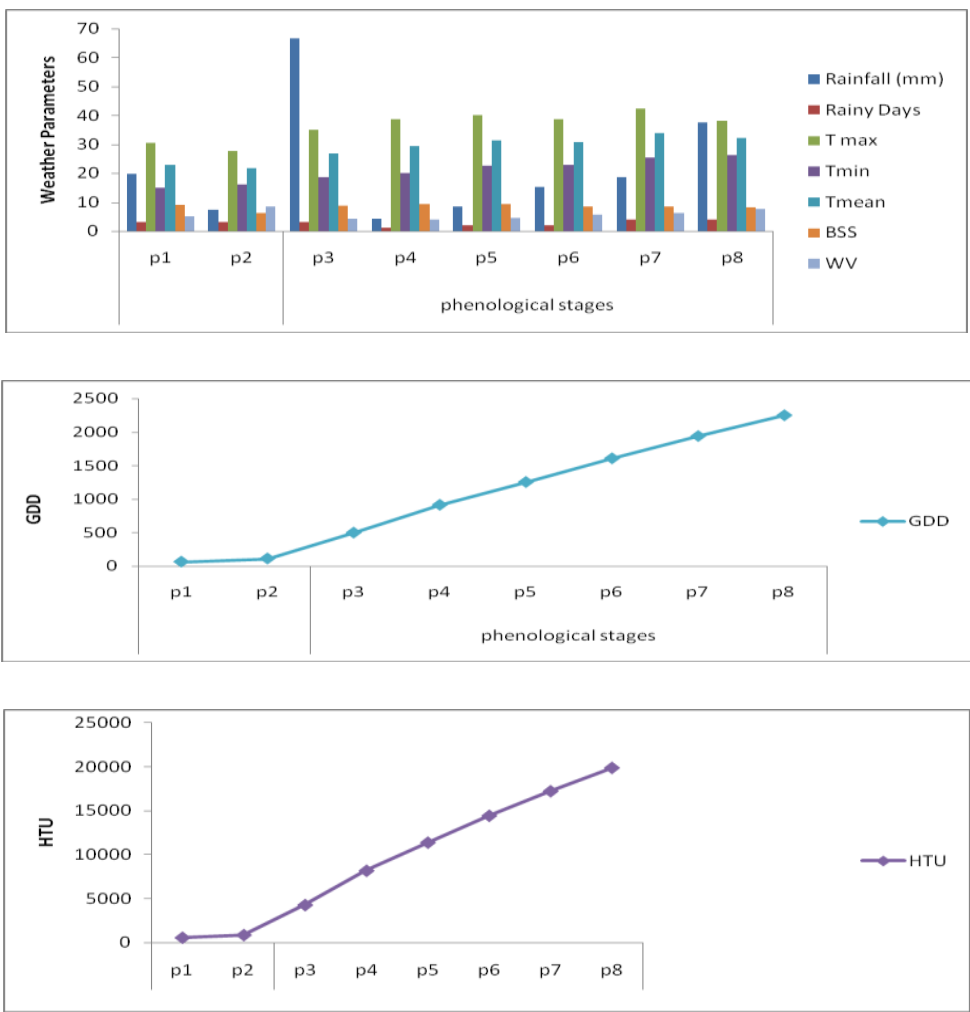

Fig.3 Variety SB-XI
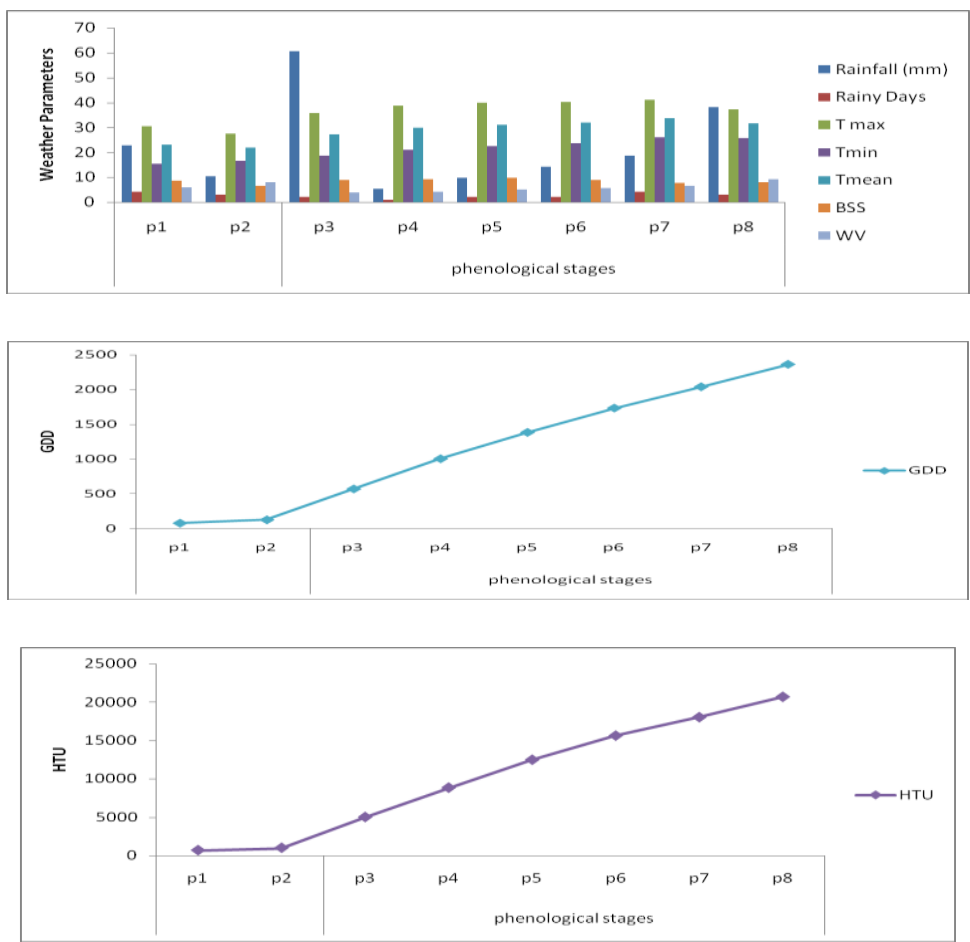
Maximum HTU requirement was observed in $\mathrm{P}_{7}$ and $\mathrm{P}_{8}$ (pod initiation to harvest) and the minimum was recorded in $\mathrm{P}_{1}$ to $\mathrm{P}_{2}$ (sowing to complete emergence). Maximum HTU required by SB-11 then by LGN-1 and less by TAG-24. This was due to the duration, temperature as well as bright sunshine hours available during the period. The sowing to germination required the lowest heliothermal unit as the duration of this phenophase was minimum. During bud emergence to flower emergence, the HTU requirement was minimum. Among the three varieties, the total HTU requirement was highest in case of SB$\mathrm{XI}$ followed by LGN-1 and less in TAG-24.

The data on yield attributing characters were presented in table 2. The data revealed that biological yield, pod yield and haulm yield was significantly influenced by different land configurations.

The land configuration Broad bed furrow recorded highest yield $(1872 \mathrm{Kg} / \mathrm{ha})$ and it was comparable with land configuration Ridges and furrow (1638 Kg/ha) and significantly superior over sara $(1562 \mathrm{Kg} / \mathrm{ha})$ and flat bed (1480 Kg/ha).
The data on yield attributing characters were presented in table 2 . The data revealed that biological yield, pod yield and haulm yield was significantly influenced by different varieties. The groundnut variety TAG-24 recorded highest and it was comparable with variety LGN-1 and significantly superior over SB-XI.

\section{References}

Basu, S., Parya, M., Dutta, S.K., Jena, S., Maji, S., Nath, R., Mazumdar, D. And Chakraborty, P.K. 2012. Effect of growing degree day on different growth processes of wheat (Triticum aestivum L.). J. Crop Weed, 8:18-22.

Bishnoi, O.P., Singh, S. and Niwas, R. 1995. Effect of temperature on phenological development of wheat (Triticum aestivum L.) crop in different row orientations. Indian J. Agric. Sci., 65: 211-14.

Borreani, G., Peiretti, P.G. and Tabacco, E. 2007. Effect of harvest time on yield and pre-harvest quality of semi-leafless grain peas (Pisum sativum L.) as wholecrop forage. Field Crops Res., 100: 1- 9.

\section{How to cite this article:}

Khade, S. S., B. V. Asewar, B. R. Bobade and Lalita Verma. 2021. Effect of Heat Units on Growth and Yield of Groundnut Varieties under Different Planting Methods in Summer Season. Int.J.Curr.Microbiol.App.Sci. 10(02): 1271-1277. doi: https://doi.org/10.20546/ijcmas.2021.1002.150 